\section{CAREERS}

Where Will They 6o?

THE training of high energy physicists and molecular spectroscopists in universities "makes them worse than useless" in industry, according to Dr D. T. Swift-Hook, head of electrical research at the CEGB laboratories at Marsham. Dr Swift-Hook, who was addressing a meeting at the Physics Exhibition last week on careers for physicists, favoured a PhD which was "goal oriented" and he would like to encourage more PhDs to be done within industry.

A physicist entering industry with a $\mathrm{PhD}$ takes several years to catch up with salary that he has lost because he did not sell his soul to some company after his first degree. Dr Swift-Hook did admit, however, that $\mathrm{PhDs}$ usually command a salary some $10-15$ per cent higher than a physicist without such qualifications, but an MSc graduate, in general, does not do better than a BSc. Dr Swift-Hook attributed this to the underlying motives of students who study for MSc degrees-he suggested that students who embarked on such courses were mostly covering up a bad first degree or they were PhDs who had failed to make the grade.

The Central Electricity Generating Board restricts its recruiting to people under the age of 26 . The reason for this, according to Dr Swift-Hook, is that the research worker is past his prime at thirty and that research managers have great difficulty keeping the average age of scientists in the laboratories below thirty without having additional complications introduced by recruiting people who are in their late twenties. Dr SwiftHook said that it was a problem of what to do with the older scientist, as not all of them had the potential to become managers.

Of more benefit to physicists and career advisors was the talk given by Mr P. L. Flowerday, assistant secretary of the Institute of Physics, who attempted to pinpoint areas where there would be vacancies for this summer's crop of graduating physicists. There are 26,000 physicists in Britain at present, a number that is being added to at the now constant rate of 2,200 fresh graduates a year. Of these nearly 10,000 are in education in one form or other and this year $\mathrm{Mr}$ Flowerday estimates there will be a need for 500 to 750 more physicists in this sector. The public sector which includes the Atomic Energy Authority, Research Associations and the Health Service and has 5,000 physicists in its ranks is experiencing a period of stagnation and there is little prospect of many physicists finding jobs here this autumn.

There are 8,000 physicists in industry at present and $\mathrm{Mr}$ Flowerday reckons that only $500-600$ more new physicists will be needed this year and these will probably have to diversify into fields not normally filled by physicists. The remaining graduates, said $\mathrm{Mr}$ Flowerday, will have to find employment in fields such as commerce and it is here that at least 500 graduates will have to deploy their talents this year. The situation, according to $\mathrm{Mr}$ Flowerday, is no worse than last year and returns of employment of 1971 graduates showed, last December, that no more physicists were unemployed then than there were in 1969 or 1970 . Prospective graduate physicists should heed $\mathrm{Mr}$ Flowerday's closing words when they look for employment: "be prepared to diversify and good luck".

\section{CHEMICAL EDUCATION}

\section{ICI Makes a New Move}

LAST week saw the publication of the first eight of a series of booklets written jointly by chemistry teachers and chemists from ICI with sixth form project work in mind. ICI says that the booklets are designed to form the basis of a kind of personal library, which might grow as samples, photographs and articles are collected by sixth formers according to their individual interests.

One of the guiding spirits behind the scheme has been Dr Duncan Davies, general manager in charge of ICI's research and development effort. $\mathrm{Dr}$
Davies said last week that it is not paradoxical to find ICI involving itself in chemical education in schools at a time when jobs for chemistry graduates are in short supply, because "chemistry is a socially central subject" and good chemistry teaching therefore needs to be encouraged. He also emphasized that ICI's position in the new scheme is as a participant and not as a patron, which is why a slightly subsidized charge of $£ 1$ is being made for the first group of eight publications. This also means that reprinting or revising as necessary is not too strongly dependent on the funds available for educational projects at any future time.

The eight booklets-on subjects rang. ing from polymers to spectroscopywere the fruits of three days of concentrated work at the University of York when the ICI schools liaison officer, Mr R. Finch, once a chemistry teacher himself, gathered together some thirty scientists, teachers and lecturers. The result is what $\mathrm{Mr}$ Finch hopes is "a collection of up-to-date material written at the right level and directly useful in the teaching of sixth form chemistry". He describes them as "project starters rather than encyclopaedias". The first reaction of Mr Martyn Berry, head of the chemistry department at Sidcup and Chislehurst Grammar School for Boys, was that the new publications would probably be a useful complement to Nuffield A-level chemistry courses.

\title{
COMMON MARKET
}

\section{Facts and Figures for the Future}

Wirt less than ten months to go before Britain, parliament and the French electorate willing, joins the European Economic Community, the data given

in the following table shows how the expanded community will fare in the world economic league table. The figures are for 1970.

Table 1. A Comparison of Economic and Industrial Power *

\begin{tabular}{|c|c|c|c|c|c|}
\hline & Six & Ten & USA & USSR & Japan \\
\hline Population (in millions) & 189.8 & 257.2 & 205.4 & 244.0 & 103.5 \\
\hline Gross National Product (in $\$ 10^{9}$ ) & 485.2 & 637.4 & 933.3 & $288+$ & - \\
\hline Imports (percentage of world total) & 30.3 & (18.3) 41.0 & 13.7 & 4.0 & 6.5 \\
\hline Exports (percentage of world total) & 31.8( & (19.2) 41.2 & 15.5 & 4.6 & 6.9 \\
\hline \multicolumn{5}{|l|}{ Production of primary energy } & 71.4 \\
\hline \multicolumn{6}{|l|}{$\begin{array}{l}\text { Internal ccnsumption of primary } \\
\text { energy (million tons of coal }\end{array}$} \\
\hline equivalent) & 845.8 & $1,235.8$ & $2,250.6$ & - & 379.6 \\
\hline Mineral oil production (million tons) & 391.7 & 504.2 & 565.5 & - & 159.7 \\
\hline Electricity production $\left(10^{6} \mathrm{MWh}\right)$ & 580.4 & 909.2 & 1738.1 & 740.9 & 350.6 \\
\hline Steel production (million tons) & 109.2 & 138.9 & 122.1 & 116.0 & 93.3 \\
\hline Automobile production ( $10^{6}$ units) & 8,029 & 9,670 & 6,550 & 348 & 3,179 \\
\hline Railways (millions of passenger $\mathrm{km}$ ) & 120,171 & 155,748 & 10,568 & 266,300 & $181,921 \ddagger$ \\
\hline $\begin{array}{l}\text { Energy consumption per capita in } \\
\text { industry }(\mathrm{kWh})\end{array}$ & 1,672 & 1,736 & $(3,300)$ & $(1,896)$ & $(1,860)$ \\
\hline $\begin{array}{l}\text { Energy consumption per capita for } \\
\text { other purposes (kWh) }\end{array}$ & 1,070 & 1,387 & $(4,000)$ & (698) & $(1,228)$ \\
\hline Passenger vehicles per $10^{3}$ & & & & & \\
\hline inhabitants (January 1, 1971) & 220 & 218 & 432 & 7 & 85 \\
\hline Television sets per $10^{3}$ inhabitants & 216 & 231 & 399 & 127 & 214 \\
\hline Telephones per $10^{3}$ inhabitants & 185 & 203 & 567 & 50 & 194 \\
\hline
\end{tabular}

* Data from Commission of the European Communities. † Net material product. $\ddagger 1969$

If Figures for the six and the ten include internal imports and exports. The present external figures for the six are shown in brackets. 